Cleveland State University

\title{
EngagedScholarship@CSU
}

Scholarship Collection

Books

$1-1992$

\section{Dynamics of a Split Torque Helicopter Transmission}

\author{
Majid Rashidi \\ Cleveland State University, M.RASHIDI@csuohio.edu \\ Timothy Krantz \\ Lewis Research Center, Cleveland $\mathrm{OH}$
}

Follow this and additional works at: https://engagedscholarship.csuohio.edu/scholbks

Part of the Aerodynamics and Fluid Mechanics Commons

How does access to this work benefit you? Let us know!

\section{Recommended Citation}

Rashidi, Majid and Krantz, Timothy, "Dynamics of a Split Torque Helicopter Transmission" (1992).

Scholarship Collection. 128.

https://engagedscholarship.csuohio.edu/scholbks/128

This Book is brought to you for free and open access by the Books at EngagedScholarship@CSU. It has been accepted for inclusion in Scholarship Collection by an authorized administrator of EngagedScholarship@CSU. For more information, please contact library.es@csuohio.edu. 
NASA

\section{AD-A257 375}

Technical Memorandum 105681

\section{Dynamics of a Split Torque Helicopter Transmission}

Majid Rashidi

Cleveland State University

Cleveland, Ohio

and

Timothy Krantz

Propulsion Directorate

U.S. Army Aviation Systems Command

Lewis Research Center

Cleveland, Ohio
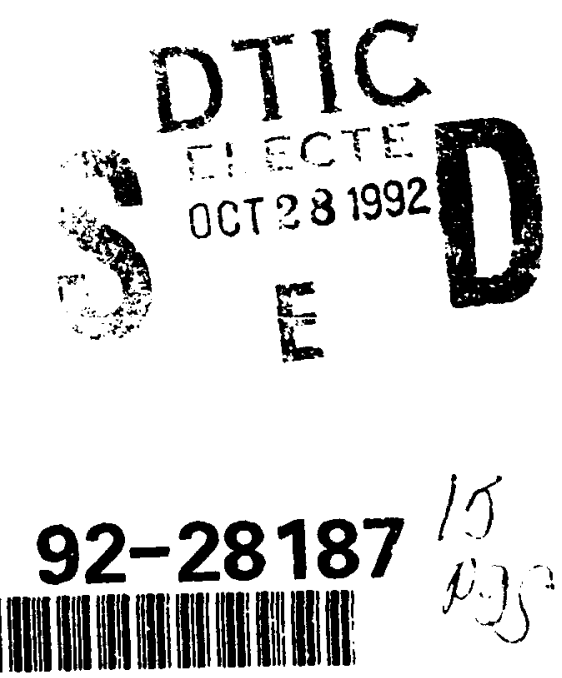

Prepared for the

Sixth International Power Transmission and Gearing Conference sponsored by the American Society of Mechanical Engineers Scottsdale, Arizona, September 13-16, 1992 


\author{
Majid Rashidi, Ph.D. \\ Mechanical Engineering Department \\ Cleveland State University \\ Cleveland, Ohio 44115 \\ and \\ Timothy Krantz \\ Propulsion Directorate \\ U.S. Army Aviation Systems Command \\ Lewis Research Center \\ Cleveland, Ohio 44135
}

DYNAMICS OF A SPLIT TORQUE HELICOPTER TRANSMISSION

\section{ABSTRACT}

A high reduction ratio split torque gear train has been proposed as an alternative to a planetary configuration for the final stage of a helicopter transmission. A split torque design allows a high ratio of power-to-weight for the transmission. The design studied in this work includes a pivoting beam that acts to balance thrust loads produced by the helical gear meshes in each of two parallel power paths. When the thrust loads are balanced, the torque is split evenly. A mathematical model was developed to study the dynamics of the system. The effects of time varying gear mesh stiffness, static transmission errors, and flexible bearing supports are included in the model. The model was demonstrated with a test case. Results show that although the gearbox has a symmetric configuration, the simulated dynamic behavior of the first and second compound gears are not the same. Also, results show that shaft location and mesh stiffness tuning are significant design parameters that influence the motions of the system.

\section{NOMENCLATURE}

B

C

E

e

K

$\overline{\mathbf{K}}$

$$
\mathbf{L}
$$

- $\mathbf{M}$

m energy dissipation function

damping coefficient

mean value of displacement element function

displacement element length

stiffness

mean value of stiffness

Lagrangian

mass

unit of length, $\mathrm{m}$

unit of force, Newton t

V

$X, Y, Z$

-

$\bullet$

$\alpha_{\mathbf{k}}$

$\beta$

$\Psi$

$\zeta$

$\Omega$

$\omega$

$\phi$

Subscripts:

a

B

b

bal generalized force

generalized coordinate

gear base radius

total kinetic energy

time

total potential energy

displacement in $X, Y, Z$ direction

first time derivative

second time derivative

angles defining locations of shafts $(k=1,2, p$, and $B)$

helix angle of helical gears

angular displacement of gears

damping ratio

fundamental mesh frequency

input shaft speed

phase angle of time varying functions

axial

bull gear

bearing

balancing beam 
input energy source

counter subscript for generalized coordinates

$(j=1,2,3, \ldots 18)$

output load

$\mathbf{P}$

pinion

shaft

$\mathbf{s}$

sB shaft between bull gear and output load

sp shaft between pinion and input energy source

s1,s2 shaft between spur and helical gear of 1st, 2nd compound gear

$\mathrm{xxbB}$ bearing of bull gear in $\mathrm{X}$ direction

$\mathrm{xxbp} \quad$ bearing of pinion gear in $\mathrm{X}$ direction

xxb1,xxb2 bearing of 1st, 2nd compound gear in X direction

yybB bearing of bull gear in $\mathbf{Y}$ direction

yybp bearing of pinion gear in $\mathbf{Y}$ direction

yyb1,yyb2 bearing of 1st, 2nd compound gear in $Y$ direction

$\mathrm{z} 1, \mathrm{z2}$ axial direction of 1 st, $2 \mathrm{r}_{\mathrm{d}} \mathrm{d}$ compound gear

1,21 1st, 2nd compound gear

1h,2h 1st, 2nd helical gear

Imh,2mh 1st, 2nd helical mesh (pinion and compound gear)

1s,2s 1st, 2nd spur mesh (compound and bull gear)

\section{INTRODUCTION}

Helicopter transmissions have evolved to a high degree of performance through the combined efforts of analysis, experiments, and application of field experience. Further improvements in performance are desired, especially decreased weight, less noise, and improved reliability. Helicopter transmissions are typical of stateof-the-art systems in that computational tools are being used to develop and improve both new designs and existing components. Dynamic simulation of advanced transmissions can reduce development cost for new configurations compared to development by experimental methods which require expensive hardware.

The most common final stage for a helicopter transmission is an epicyclic configuration which features an output shaft driven by several planets. This arrangement divides the transmitted torque among several planets. Epicyclic gear trains have been studied both analytically and experimentally (.August et al., 1984; Choy et al., 1987; Choy et al., 1988; Zakrajsek, 1989).

An alternative to an picyclic stage which also transfers power to the output shaft tirough multiple paths is a split torque stage. One configuration for a split torque stage proposed for a helicopter application is shown in Fig. 1. White (1982) states that this new split torque gear train not only offers an overall weight reduction, but also promises the following advantages compared to the conventional epicyclic helicopter transmission:

(1) High ratio of speed reduction at final stage

(2) Reduced number of speed reduction stages



Figure 1.-Pictorial view of a split-torque helicopter transmission with two power paths.

(3) Lower energy losses

(4) Increased reliability of the separate drive paths

(5) Fewer gears and bearings

(6) Lower noise.

The above advantages suggest the development of a new generation of helicopter transmissions of the split torque type shown in Fig. 1.

A recent study on a split torque helicopter transmission is that of D. Hochmann et al. (1991). They analyzed the load distribution of spur and double helical gear pairs used in a split torque helicopter transmission. They concluded from their analysis that gear tooth profile modifications and staggered phasing of a double helical gear mesh can greatly reduce loaded static transmission error without seriously degrading load distribution.

An aspect of split torque configurations that has not been rigorously studied is the overall dynamic behavior. A special characteristic of split torque drivetrains is the use of some method or mechanism to guarantee that the power is split evenly among the parallel paths. Several different methods have been proposed (Coy and Bill, 1988; Fisher, 1981; White, 1974, 1982, 1983, 1987, 1989). An appropriate analytical model is needed to study the system dynamics of these designs. The purpose of this study is to provide a mathematical model to analyze the dynamic and vibration characteristics of split torque transmissions and to use the model to perform some analytical studies.

\section{SPLIT TORQUE TRANSMISSION}

The split torque transmission considered in this study is shown pictorially in Fig. 1 and schematically in Fig. 2. The pinion transfers input torque to a set of two compound helical/spur gears via the helical meshes. The two spur pinions of these compound gears transfer the power into a final stage bull gear. The two helical meshes produce thrust loads that are reacted through a pivoted balancing beam. The function of the balancing beam is to couple the axial positions of the compound gears sucb that the thrust loads and therefore the torques of the two helical gears are equal.

One of the main objectives of this work is to identify the key design parameters that influence the overall dynamic behavior of this system. Among the important parameters are the angles between the centerlines of the gears as identified in Fig. 2. These angles influence the stiffness properties of the system (appendix $A$ ). Also, for a given set of gears, these angles define the relative phasing 




Figure 2.-Top view of the split-torque gear train with angles $\alpha_{1}$,

$\alpha_{2}, \alpha_{p}$, and $\alpha_{B}$ depicting the shaft locations on the gear box.

of the time-varying mesh stiffnesses. Note that although the gear train is geometrically symmetric with respect to the centerlines of the gearbox, the static bearing force reactions of the two identical compound gears are not equal.

The mathematical model developed in this study may be used to understand and predict the effect of design parameters on the performance of the system. The important properties that can be simulated by the model can be categorized as:

(1) Microgeometric parameters such as shaft hub eccentricities, tooth profile geometry, tooth spacing, lead, and profile errors.

(2) Macrogeometric parameters such as gear mesh pitch, pressure angles, helix angle, and shaft and bearing locations.

(3) Material properties and bulk dimensions of the components which defines the components' inertia, stiffness, and dampening properties.

(4) Type and geometry of the bearings that support the gear shafts.

\section{MATHEMATICAL MODEL}

A mathematical model has been developed to analyze the dynamic and vibration characteristics of split torque transmissions. The split torque transmission was modeled by a set of inertia, stiffness, darnping, and displacement elements. The analytical model is shown in Fig. 3. Along with the inertia and stiffness elements shown in the figure, the model also includes a damping element parallel to each stiffness element, an input inertia, and an output inertis. Displacement elements are included at the gear mesh locations as illustrated in Fig. 4. The gear mesh stiffness and displacement elements together can simulate the loaded static transmisaion error motions of the gear pairs. The displacement element is needed to simulate pitch errors and all other components of the static transmission error not attributable to the varying mesh stiffness.

The mathematical model shown in Fig. 3 can be deacribed by a total of 21 coordinates. The rotational positions of the gears, input and output inertias, and balancing beam require nine coordinates. The axial positions of the pinion, first compound gear, second compound gear, and balancing beam require four coordinates. The translationa of the gear shafts require another eight coordinates.
The mass moment of inertia of the helical pinion, the mass moment of inertia of the balancing beam, and the mass of the balancing beam were considered negligibie compared to the other inertias of the system. Under this assumption, the system is described by 18 equations of motion. The system is semidefinite and therefore has a rigid body mode.

The equations of motion of this system were derived by the standard Lagrangian method as:

$$
d \frac{\left[\left(\frac{\partial L}{\partial \dot{q}_{j}}\right)\right]}{d t}+\frac{\partial B}{\partial \dot{q}_{j}}-\frac{\partial L}{\partial q_{j}}=Q_{j} \quad(j=1,2,3, \ldots 18)
$$

where $\mathrm{L}=\mathrm{T}-\mathrm{V}, \mathrm{T}=$ Total kinetic energy, $\mathrm{V}=$ Total potential energy, $B=$ Energy dissipation function, $q_{j}=$ Generalized coordinate, $Q_{j}=$ Generalized force associated with each generalized coordinate $q_{j}$. All stiffness elements were assumed linear. The gear meshes stifiness elements were defined by time-varying periodic functions.

The kinetic energy of this system is:

$$
T=\frac{1}{2} \sum M_{j} \dot{q}_{j}^{2} \quad(j=1,2,3, \ldots 18)
$$

The energy dissipation function of this system is:

$$
B=\frac{1}{2} \sum C_{j} \dot{q}_{j}^{2} \quad(j=1,2,3, \ldots 18)
$$

Here, the damping elements were modeled with proportional damping expressed in terms of the damping ratio, $\zeta$, stiffness coefficient, $K$, and inertia, $M$, as $C=\sqrt{2 \zeta K M}$.

The potential energy is classified into four groups of stored energy caused by: (1) distortion of the gear meshes; (2) shaft trans. lations at bearing supports; $(3$, wiating of gear shafts and hubs; and (4) axial distortions of the balancing beam components and support. 


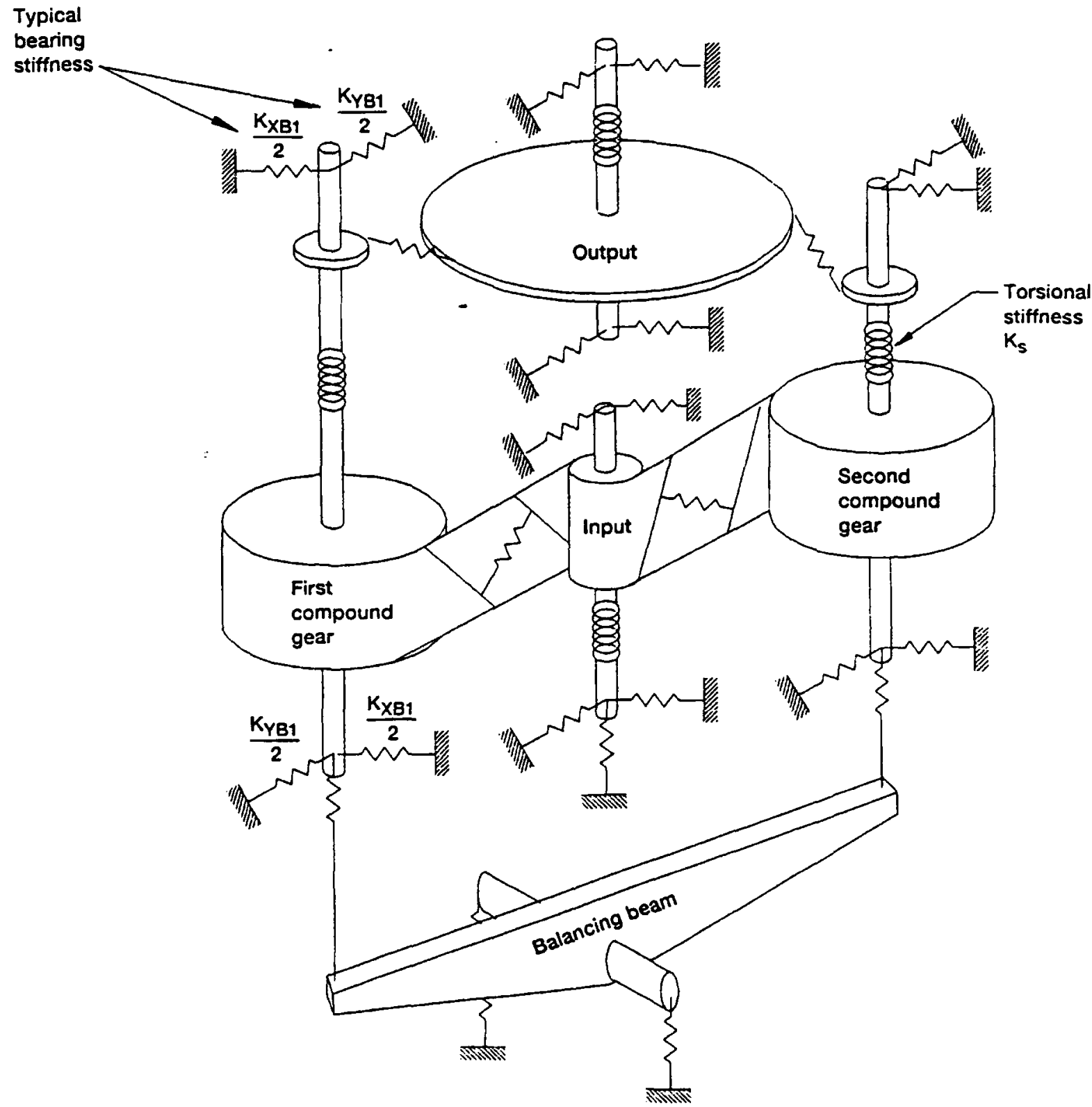

Figure 3.-Split torque model. Note: not shown, damping elements, input inertia, output inertia. 


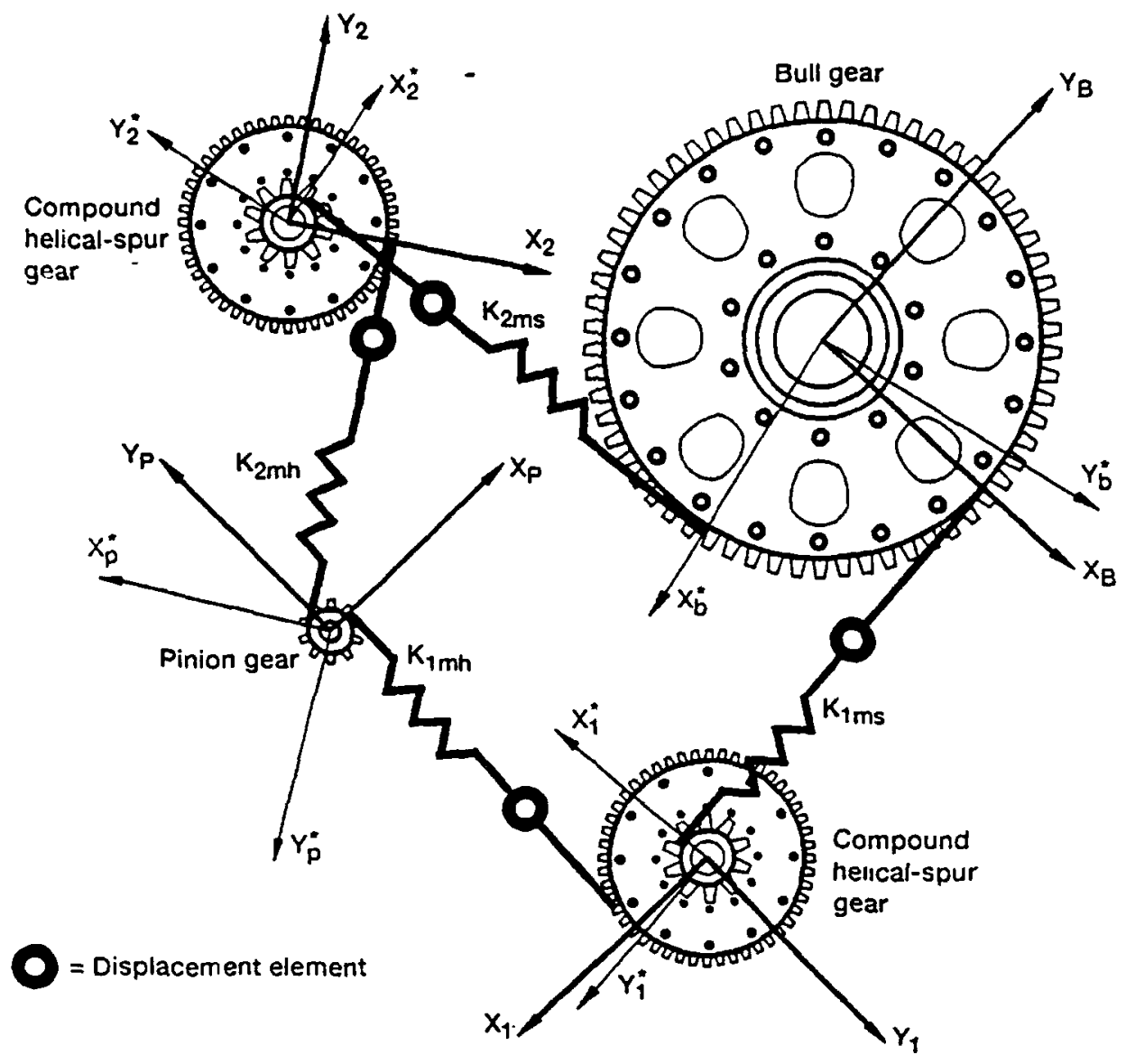

Figure 4.-Top view of the split-torque gear train, local and global reference frames.

The first group is the stored energy due to distortion of the gear meshes. These terms were first expressed in a local coordinate system as shown in Fig. 4. Reference coordinate frames with superscript $\left({ }^{*}\right)$ are local. The potential energies specified in these coordinate frames were then expressed in a global reference frame via rotational coordinate transformations. These coordinate transformations introduce the shaft locations of the gear train as design/ analysis parameters. For example, the potential energy stored in the helical mesh of the input pinon and second compound gear was expressed in the local coordinate system as:

$$
\begin{array}{r}
V_{2 m h}=\frac{1}{2} K_{2 m h}(t)\left[I_{p} \cos (\beta) \Psi_{p}-r_{2 h} \cos (\beta) \Psi_{2 h}+\cos (\beta) Y_{p}^{*}\right. \\
\left.-\cos (\beta) Y_{2}+\sin (\beta) Z_{p}-\sin (\beta) Z_{2}-e_{2 h}(t)\right]^{2}
\end{array}
$$

The local coordinate $\mathrm{Y}_{\mathrm{p}}^{*}$ was transformed by

$$
Y_{p}^{*}=Y_{p} \cos \left(\alpha_{p}\right)-X_{p} \sin \left(\alpha_{p}\right)
$$

- By applying the relation 5 to Eq. (4), the potential energy can be expressed in globsl coordinates as:

$$
\begin{array}{r}
V_{2 m h}=\frac{1}{2} K_{2 m h}(t)\left[r_{p} \cos (\beta) \Psi_{p}-r_{2 h} \cos (\beta) \Psi_{2 h}+\cos (\beta)\right. \\
\quad \times \cos \left(\alpha_{p}\right) Y_{p}-\cos (\beta) \sin \left(\alpha_{p}\right) X_{p}-\cos (\beta) Y_{2} \\
\left.+\sin (\beta) Z_{p}-\sin (\beta) Z_{2}-e_{2 h}(t)\right]^{\beta}
\end{array}
$$

The potential energy stored in the other gear meshes was derived in a similar manner.

The second group is the potential energy stored in the bearings due to shaft translations. To reduce the number of coordinates needed to describe the system, it was assumed that each gearshaft moves in pure translation and does not tilt. This assumption is reasonable when the length of the gearshaft is comparable to the face width of the gear. The bearing stiffness coefficients were defined in the global coordinate systems shown in Fig. 4. Under these conditions, the potential energy was expressed as:

$$
\begin{aligned}
& V_{b}=\frac{1}{2} K_{x x b 1} X_{1}^{2}+\frac{1}{2} K_{y y b 1} Y_{1}^{2}+\frac{1}{2} K_{x x b 2} X_{2}^{2}+\frac{1}{2} K_{y y b 2} Y_{2}^{2} \\
& +\frac{1}{2} K_{x x b p} X_{p}^{2}+\frac{1}{2} K_{y y b p} Y_{p}^{2}+\frac{1}{2} K_{x x b B} X_{B}^{2}+\frac{1}{2} K_{y y b B} Y_{B}^{2}
\end{aligned}
$$

The third group is the potential energy stored in the twisted shafts, which was expressed as:

$$
\begin{aligned}
& V_{s}=\frac{1}{2} K_{11}\left[\Psi_{1 h}-\Psi_{1 s}\right]^{2}+\frac{1}{2} K_{82}\left[\Psi_{2 h}-\Psi_{2 s}\right]^{2} \\
& \left.+\frac{1}{2} K_{s p i} \Psi_{i}-\Psi_{p}\right]^{2}+\frac{1}{2} K_{\mathrm{sB}}\left[\Psi_{B}-\Psi_{0}\right]^{2}
\end{aligned}
$$

The fourth group is the potential energy due to distortion of the balancing beam support and the elements connecting the beam to the compound gear shafts. This was expressed as: 


$$
\begin{array}{r}
\mathrm{V}_{\mathrm{a}}=\frac{1}{2} \mathrm{~K}_{\mathrm{al}}\left[\mathrm{Z}_{1}-\mathrm{L}_{\mathrm{bal}} \theta_{\mathrm{bal}}-\mathrm{Z}_{\mathrm{bal}}\right]^{2}+\frac{1}{2} \mathrm{~K}_{\mathrm{z} 2}\left[\mathrm{Z}_{2}+\mathrm{L}_{\mathrm{bal}} \theta_{\mathrm{bal}}\right. \\
\left.-\mathrm{Z}_{\mathrm{bal}}\right]^{2}+1 / 2 \mathrm{~K}_{\mathrm{bal}} \mathrm{Z}_{\mathrm{bal}}^{2}+\frac{1}{2} K_{\mathrm{ap}} \mathrm{Z}_{\mathrm{p}}^{2}
\end{array}
$$

By applying the Lagrangian method, the equations of motion were derived. A typical equation of motion is presented in appen$\operatorname{dix} A$. Bearings were assumed to be pure stiffness elements with zero damping. The equations of motion are written such that the dispiacement ejement functions $e_{i j}(t)$ appear on the right hand side of the equation as part of the generalized forcing functions $Q_{j}(t)$. The generalized forcing functions can be defined to simulate sources of excitation such as gear hub/shaft runouts and input/output torque fluctuations. However, in this study, only the static transmission error excitation as modeled by the time-varying displacernent elements and gear mesh stiffnesses excited the system. The equations of motion were transformed to dimensionless forms using certain characteristic parameters inherent in the gear train system. Appendix B includes a glossary of the dimensionless parameters and how they were included in the mathematical model.

\section{ANALYSIS AND PARAMETRIC STUDY}

The mathematical model was demonstrated with a test case to simulate the motion of a split torque transmission. A gear mesh stiffness varies in time similar to a square wave function. The gear mesh stiffness elements were defined using a seven-term Fourier series. Seven terms were judged appropriate to approximate the square wave shape. A typical series used is illustrated in Fig. 5. The Fourier series functions used approximate the magnitude and wave shape of a typical gear mesh but are not precise representations of a particular pair of gears. Displacement elements of the gear meshes were also defined using a seven-term Fourier series (Fig. 6). The displacement elements and stiffness elements together simulated typical loaded static transmission error motions. The fundamental period of each series was the corresponding gear mesh period. Dimensions and properties for geometry and inertias used in this study, given in appendix C, approximated those of the Split Torque Test Rig at the NASA Lewis Research Center. A damping ratio of $\zeta=0.01$ was assumed for all damping elements, and the bearings were assumed to be pure stiffness elements with zero damping. The method of R. Singh and T.C. Lim (1990) was used to calculate the bearing stiffness characteristics.

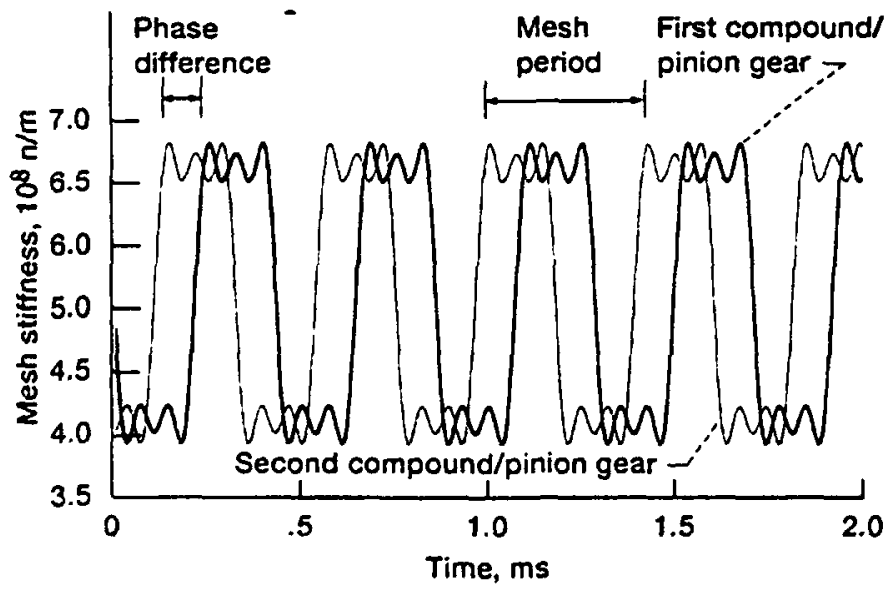

Figure 5.-Periodic behavior of the stiffnesses of the helical meshes.

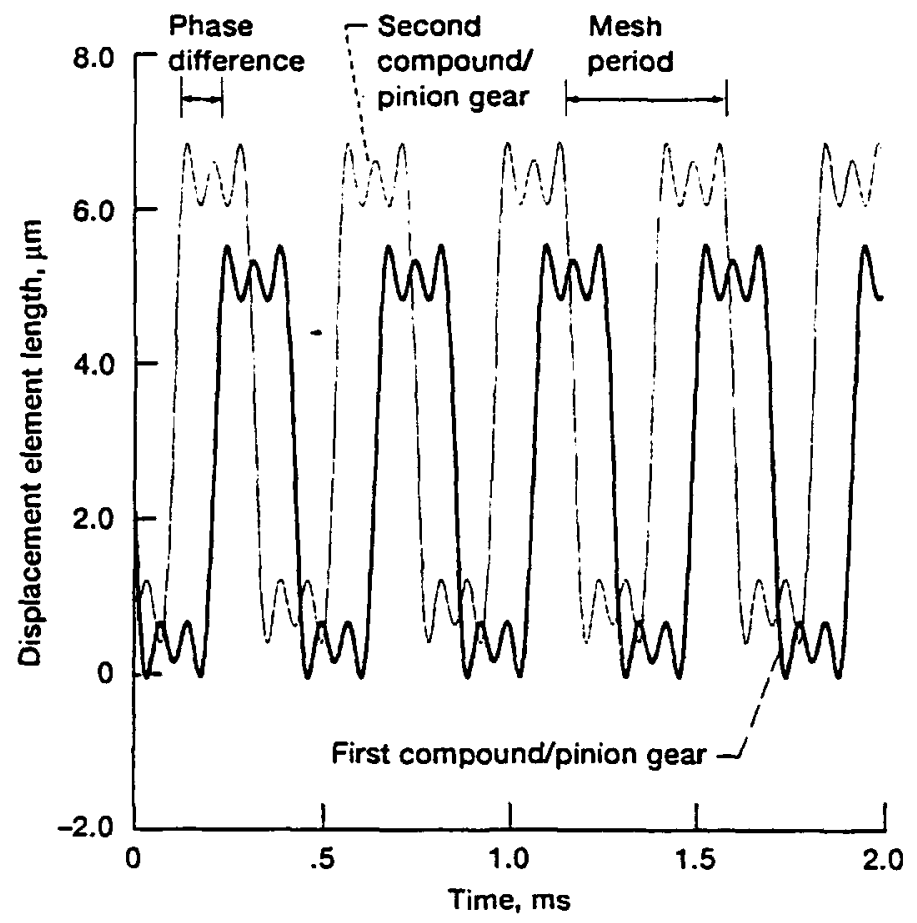

Figure 6.-Periodic behavior of displacement elements of the helical meshes.

Parametric studies were completed to examine the effects of two design parameters on the performance of the gear train. The following parameters were studied:

(1) The phase difference between the two helical gear meshes (stiffness tuning). There are two helical and two spur gear pairs in this gear system. Figure 5 illustrates a typical time variation of the stiffness properties.

(2) The shaft locations relative to one another and relative to the frame of the gear box. Figure 2 shows that these relative locations can be characterized by the angles $\alpha_{1}, \alpha_{2}, \alpha_{p}$, and $\alpha_{B}$.

The dimensionless equations of motion were integrated in time by a fifth-order/sixth-order Runge-Kutta method.

\section{RESULTS AND DISCUSSION}

The mathematical model developed in this work was used to simulate the vibratory behavior of the split torque transmission shown in Fig. 1. The source of excitation for the model was simulated static transmission errors for each gear pair. The stiffness element and displacement element at each gear mesh were defined appropriately to simulate typical static transmission errors for precision gears. All of the geometric and dynamic parameters were expressed in dimensionless forms. Figures 7 to 16 show some of the simulated motions of the system in generalized coordinates. These results were obtained for the case of an input pinion speed of $\omega_{p}=8778 \mathrm{rpm}$ and an input pinion torque of $405 \mathrm{~N}-\mathrm{m}$. In this case the pinion was positioned between the two compound gears such that the centerlines of the compound gears and the pinion lie on a straight line, in other words, $\alpha_{p}=180^{\circ}$.

The effects of relative shaft locations $\left(\alpha_{1}, \alpha_{2}, \alpha_{p}\right.$, and $\left.\alpha_{B}\right)$ and of mesh stiffness tuning were studied. Here, mesh stiffness tuning is considered to be the adjustment of the phase difference between the periodic mesh stiffnesses of the first and second compound gears, $\phi_{1 m h}-\phi_{2 m h}$ (Fig. 5). The results are contained in Tables I and II, respectively. Table II(a) contains the maximum shaft orbit radii which are computed from $X_{i}^{2}+Z_{j}^{2}$ for $j=1,2, p$, and $B$. 




Figure 7.-Displacement of the first compound gear shaft in $X$ direction versus time.

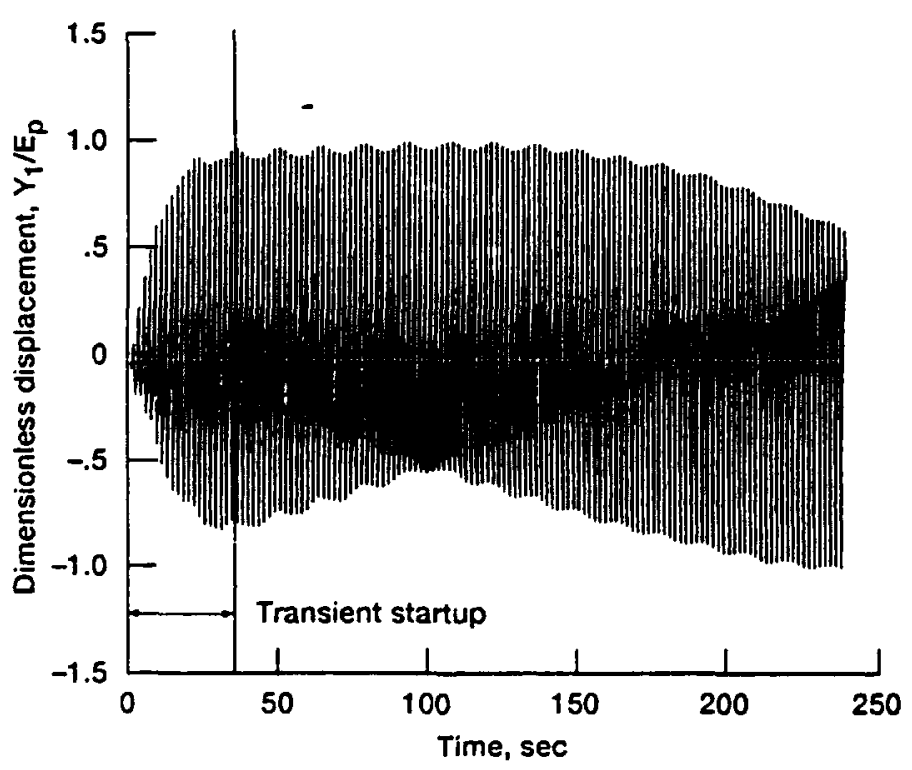

Figure 8.-Displacement of the first compound gear shaft in $Y$ direction versus time.

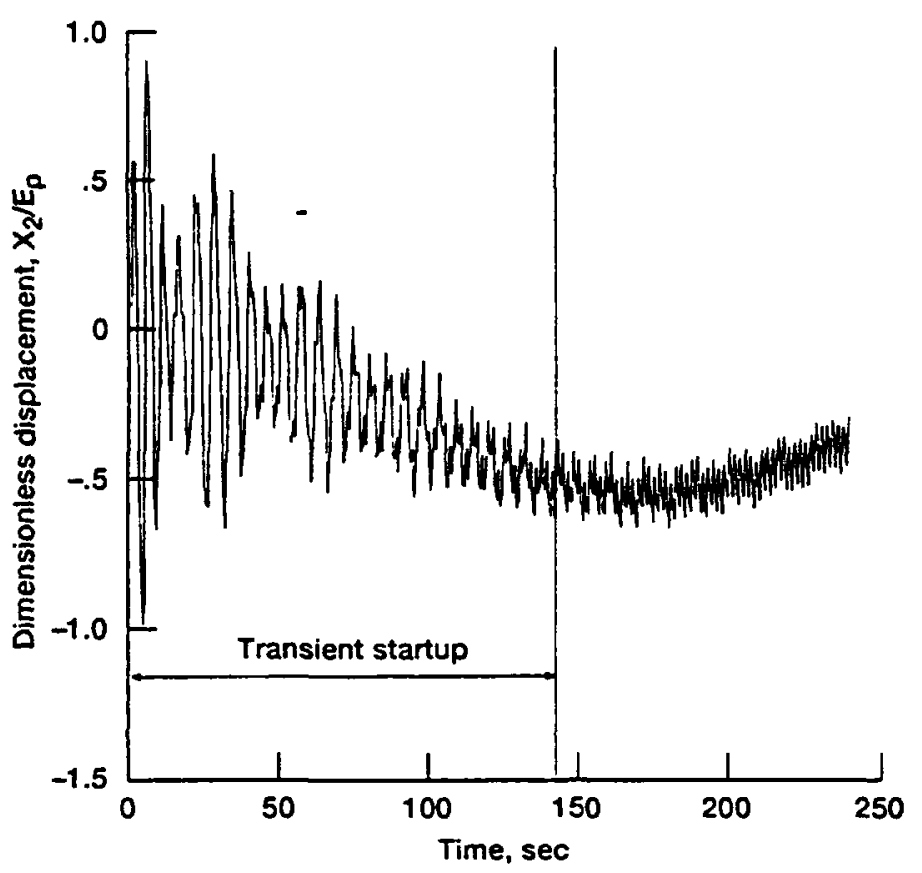

Figure 9.-Displacement of the second compound gear shaft in $\mathrm{X}$ direction versus time.

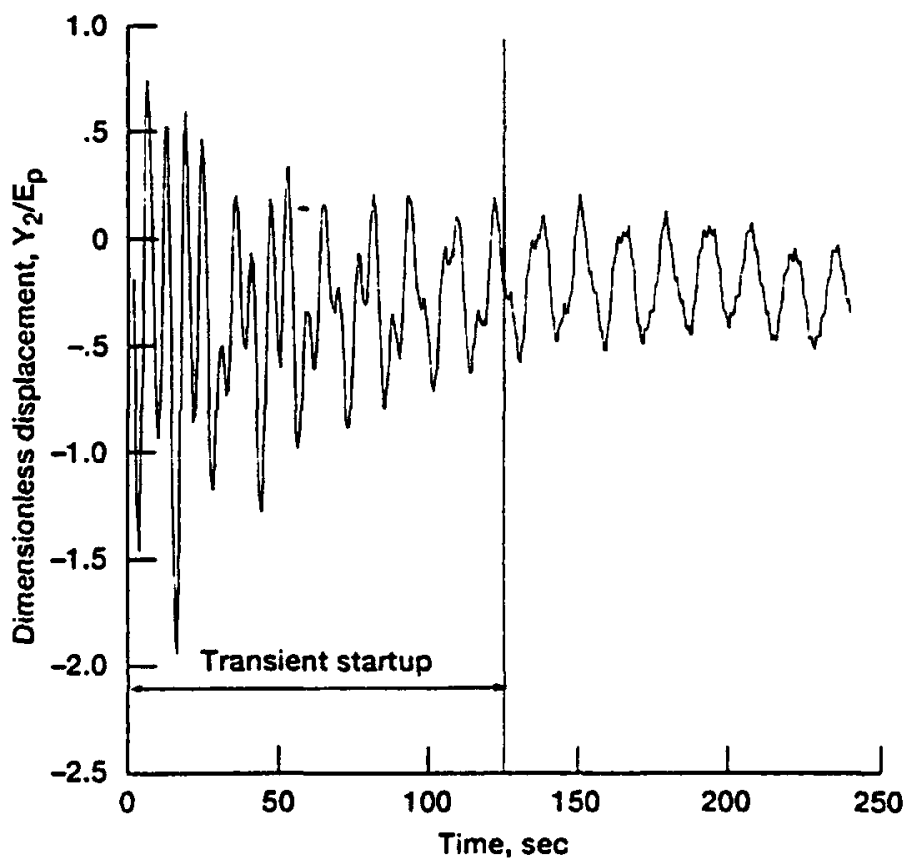

Figure 10.-Displacement of the second compound gear shaft in $Y$ direction versus time. 


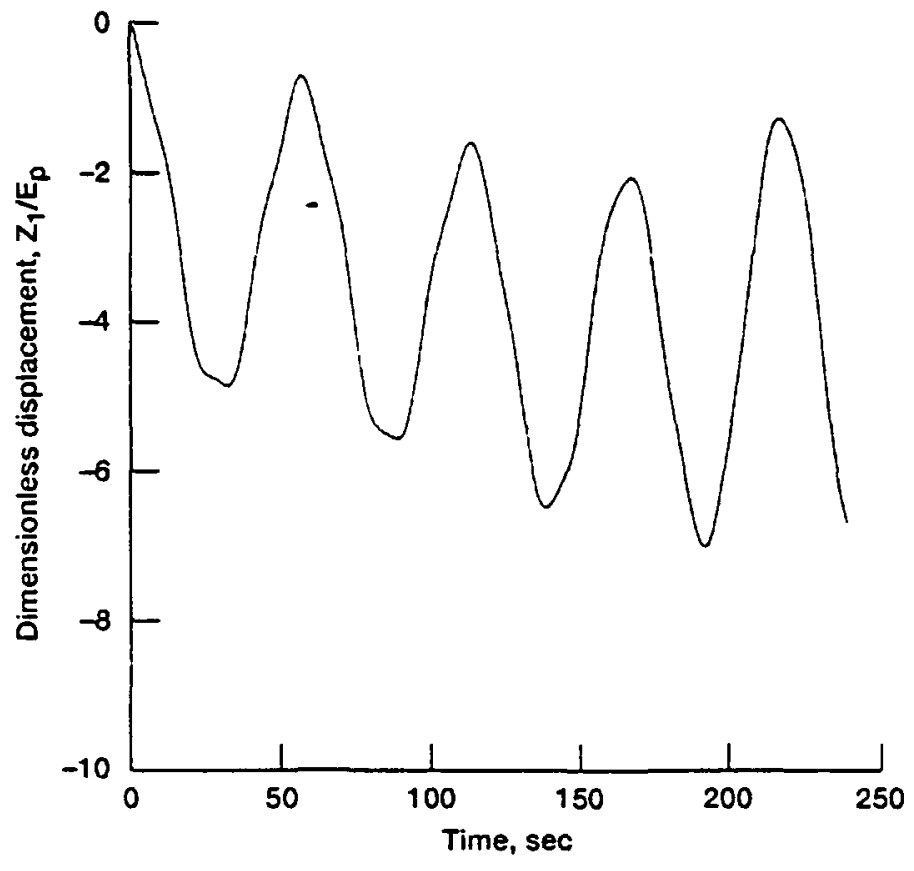

Figure 11.-Axial displacement of the first compound gear shaft in $\mathbf{Z}$ direction.

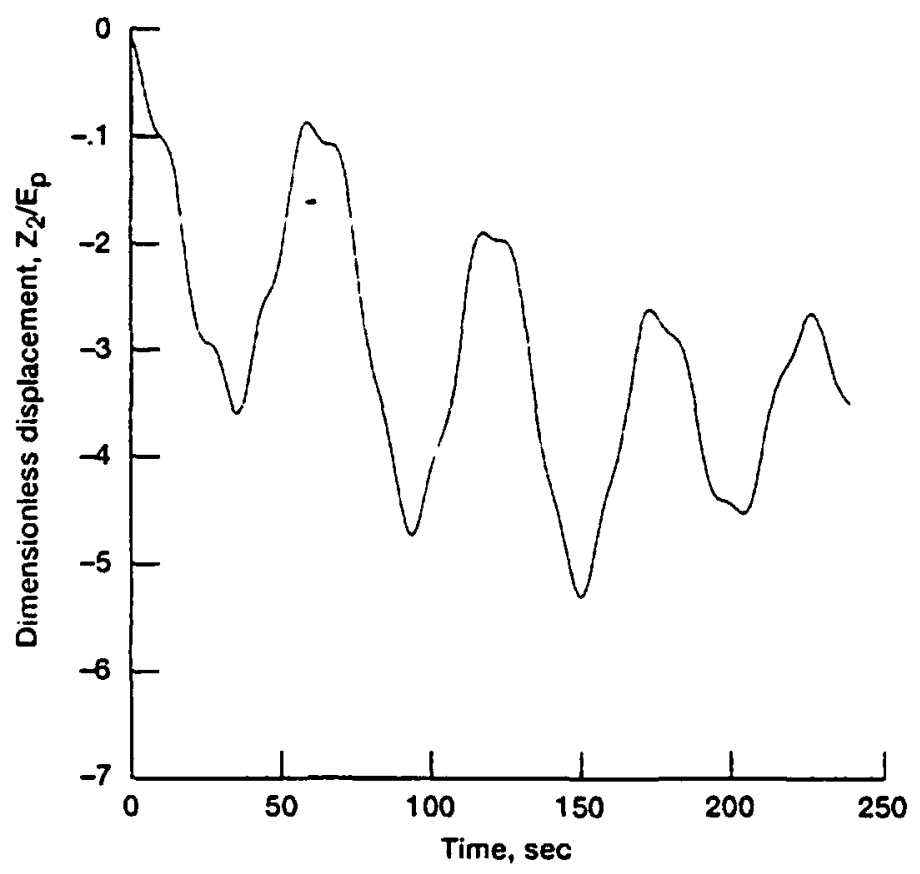

Figure 12.-Axial displacement of the second compound gear shaft in $\mathbf{Z}$ direction.

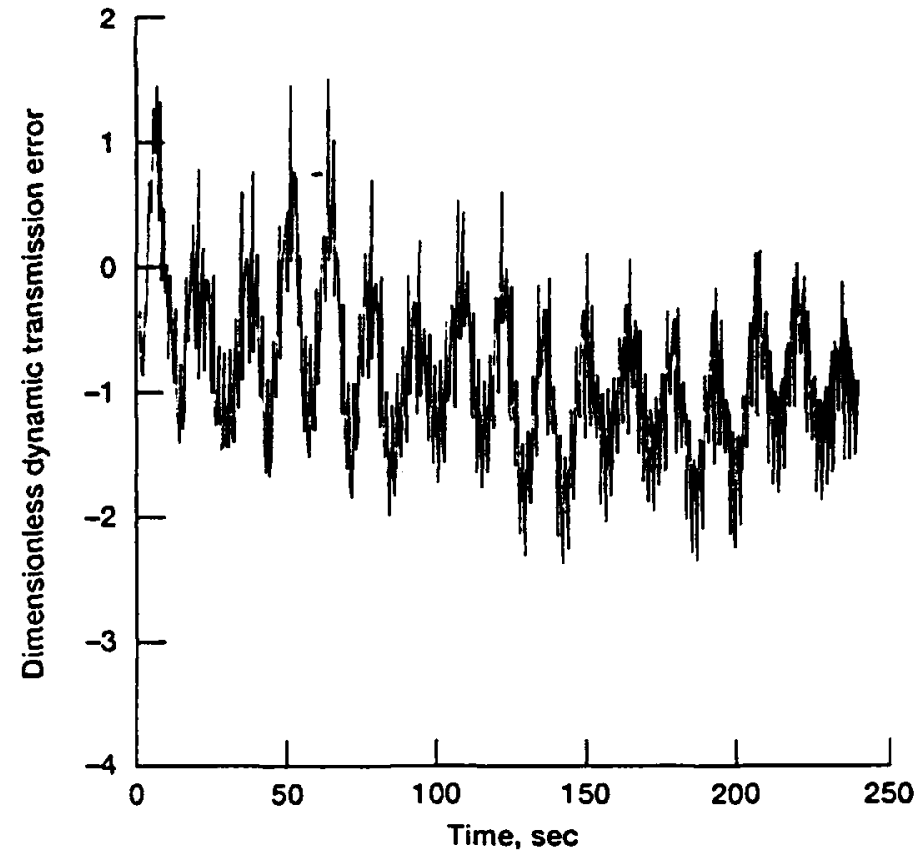

Figure 13.-Dynamic transmission error of the pinion and first helical compound gear, $\psi_{p}-\psi_{1 h}$.

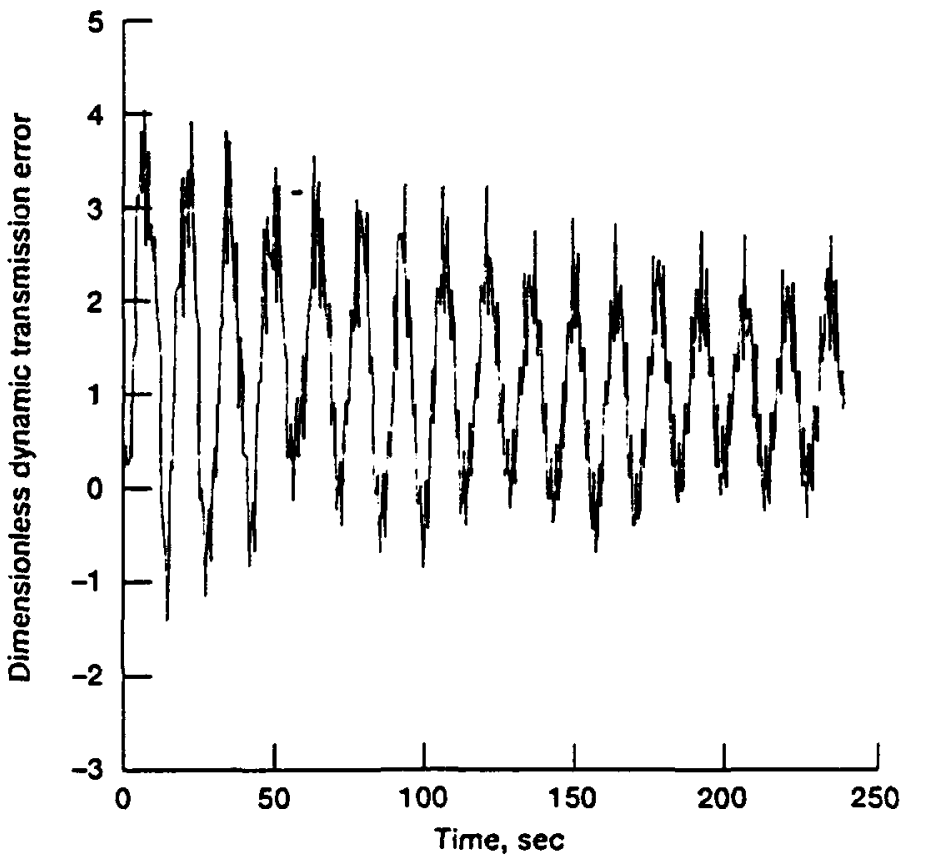

Figure 14.-Dynamic transmission error of the pinion and second helical compound gear, $\psi_{p}-\psi_{2 h}$. 


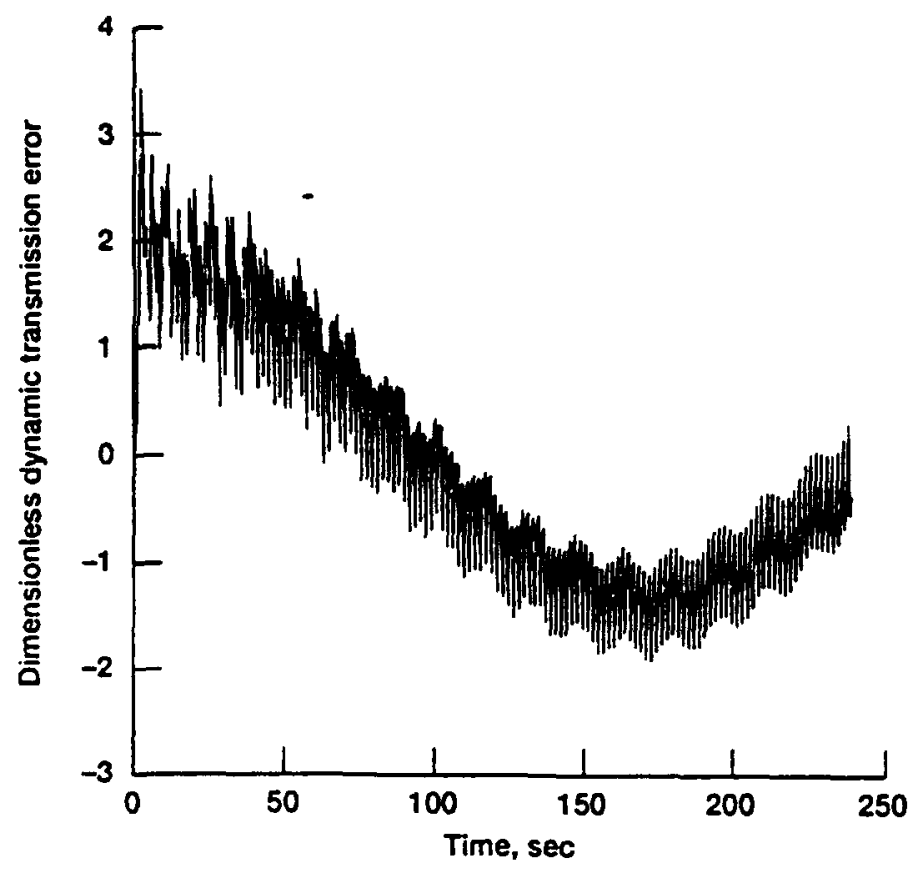

Figure 15.-Dynamic transmission error of the bull and first spur compound gear, $\psi_{B}-\psi_{15}$.

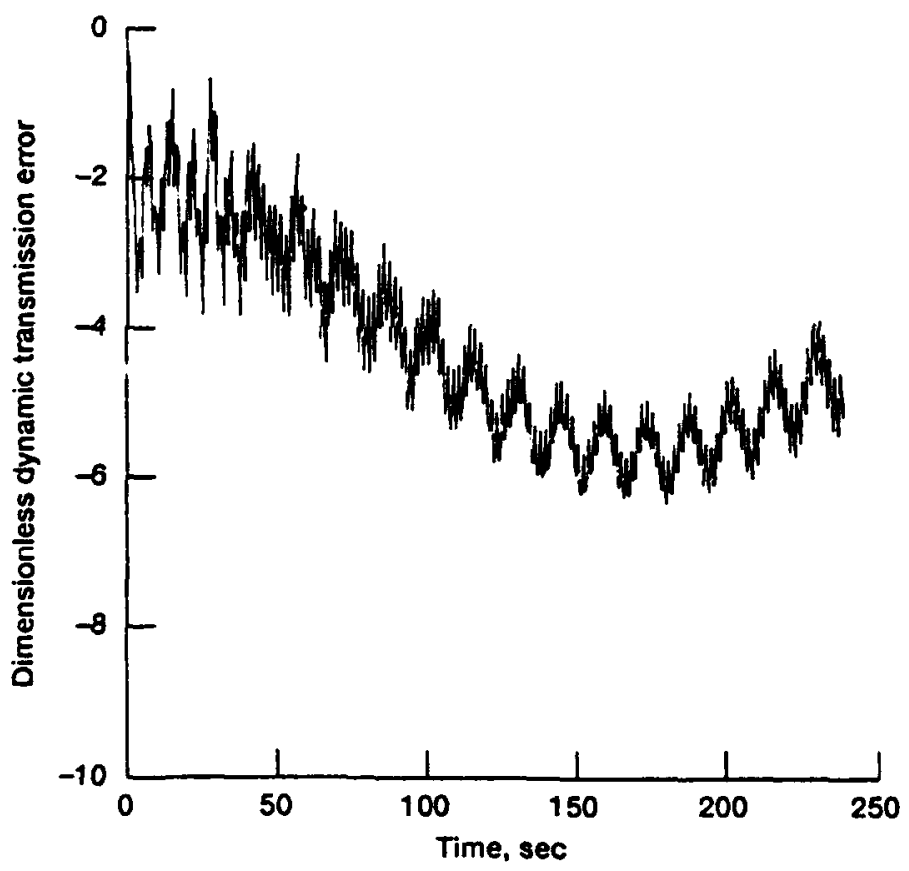

Figure 16.-Dynamic transmission error of the bull and second spur compound gear, $\Psi_{B}-\psi_{2 s}$.

TABLE I. - EFFECT OF SHAFT LOCATIONS ON GEARBOX VIBRATIONS

(a) Lateral vibretion of ahetes

\begin{tabular}{|c|c|c|c|c|}
\hline & \multicolumn{4}{|c|}{  } \\
\hline $\begin{array}{l}\text { Shan } \\
\text { bocentoa, } \\
\text { des }\end{array}$ & $\begin{array}{l}\text { Int compousd } \\
\text { cent }\end{array}$ & $\begin{array}{c}\text { 2ad compound } \\
\text { aes }\end{array}$ & Plaion & Bull rour \\
\hline $\begin{array}{l}a_{1}=93.7 \\
a_{1}=50.0 \\
a_{p}=120.0\end{array}$ & 0.4 & 0.8 & 1.7 & 0.3 \\
\hline $\begin{array}{l}a_{1}=68.2 \\
a_{1}=57.3 \\
a_{p}=166.2\end{array}$ & 0.5 & 0.5 & 0.4 & 0.4 \\
\hline $\begin{array}{l}a_{1}=61.1 \\
a_{1}=57.8 \\
a_{p}=100.0\end{array}$ & 1.4 & 0.6 & $1 \times 10^{-4}$ & 0.3 \\
\hline
\end{tabular}

(b) Axial vibraclon of ebalte.

\begin{tabular}{|c|c|c|c|}
\hline & \multicolumn{3}{|c|}{ Meximne dimeacioslene vibration emplitude } \\
\hline $\begin{array}{l}\text { Shatt } \\
\text { locestoo, } \\
\text { des }\end{array}$ & $\begin{array}{l}\text { In compound } \\
\text { sear }\end{array}$ & $\begin{array}{c}\text { 2ad cosponed } \\
\text { sent }\end{array}$ & Pidios \\
\hline $\begin{array}{l}a_{1}=93.7 \\
a_{1}=50.0 \\
a_{p}=120.0\end{array}$ & 2.5 & 2.5 & 0.3 \\
\hline $\begin{array}{l}a_{1}=65.2 \\
a_{1}=57.3 \\
a_{p}=166.2\end{array}$ & 2.0 & 1.8 & 0.02 \\
\hline $\begin{array}{l}\alpha_{2}=61.1 \\
\alpha_{3}=57.8 \\
a_{p}=180.0\end{array}$ & 2.0 & 1.5 & 0.02 \\
\hline
\end{tabular}

(c) Ancrales vibration of ener patrs

\begin{tabular}{|c|c|c|c|}
\hline & \multicolumn{3}{|c|}{ 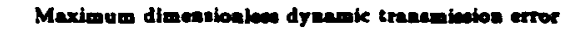 } \\
\hline $\begin{array}{l}\text { Shart } \\
\text { bocatbo, } \\
\text { det }\end{array}$ & $v_{1}-v_{1 b}$ & $v_{p}-v_{2}$ & $\varphi_{10}-\varphi_{1}$ \\
\hline $\begin{array}{l}a_{1}=93.7 \\
a_{1}=50.0 \\
a_{p}=120.0\end{array}$ & 2.0 & 1.0 & 0.8 \\
\hline $\begin{array}{l}a_{1}=69.2 \\
a_{8}=57.3 \\
a_{p}=166.2\end{array}$ & 1.0 & 1.8 & 0.5 \\
\hline $\begin{array}{l}a_{1}=\$ 1.1 \\
a_{0}=57.8 \\
a_{p}=180.0\end{array}$ & $\mathbf{1}$ & 1.5 & 0.8 \\
\hline
\end{tabular}


TABLE II. - EFFECT OF MESH STIFFNESS TUNING ON GEARBOX VIBRATION

(a) Lateral vibretion of whafts

\begin{tabular}{|c|c|c|c|c|}
\hline & \multicolumn{4}{|c|}{ Meximum dimenaiosles shaft orbit redius } \\
\hline 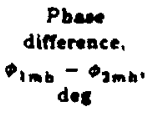 & $\begin{array}{l}\text { lat compound } \\
\text { sees }\end{array}$ & $\begin{array}{l}\text { 2ad compound } \\
\text { gear }\end{array}$ & Pinion & Buil gear \\
\hline 0.0 & 0.4 & 0.8 & 1.2 & 0.3 \\
\hline 3.6 & 1.6 & 1.1 & 1.3 & 0.3 \\
\hline 36.0 & 16.2 & 7.1 & 1.7 & 1.3 \\
\hline 90.0 & 42.7 & 17.1 & 2.7 & 3.0 \\
\hline 180.0 & 53.65 & 25.1 & 3.6 & 4.5 \\
\hline
\end{tabular}

(b) Axial vibretion of abafte

\begin{tabular}{|c|c|c|c|}
\hline & \multicolumn{3}{|c|}{ Maximum dimeneionlen vibretion amplitude } \\
\hline $\begin{array}{c}\text { Phace } \\
\text { difference, } \\
\phi_{1 \text { b }}-\phi_{2 m b} \text {, }\end{array}$ & $\begin{array}{l}\text { lilt compaund } \\
\text { sear }\end{array}$ & $\begin{array}{l}\text { 2nd compound } \\
\text { sear }\end{array}$ & Pinion \\
\hline 0.0 & 2.5 & 2.5 & 0.3 \\
\hline 3.6 & 2.5 & 2.0 & 0.2 \\
\hline 36.0 & 2.5 & $\mathbf{2 . 0}$ & 0.2 \\
\hline 90.0 & 2.0 & 1.7 & 0.2 \\
\hline 180.0 & 1.8 & 1.5 & 0.2 \\
\hline
\end{tabular}

(c) Angular vibration of gear pairs

\begin{tabular}{|c|c|c|c|}
\hline & \multicolumn{3}{|c|}{ Maximum dimentionlew dy uemic trangmintion error } \\
\hline $\begin{array}{c}\text { Phave } \\
\text { diflerence. } \\
\phi_{1 \mathrm{mb}}-\phi_{2 \mathrm{~m}} \text {. } \\
\text { deg }\end{array}$ & $v_{p}-\theta_{1 b}$ & $a_{p}-v_{2 b}$ & $9,-0$ \\
\hline 0.0 & 2.0 & 1.0 & 0.8 \\
\hline 3.6 & 2.0 & 1.0 & 7.0 \\
\hline 36.0 & 4.0 & 3.0 & 60.0 \\
\hline 90.0 & 5.0 & 4.0 & 160.0 \\
\hline 180.0 & 10.0 & 8.0 & 200.0 \\
\hline
\end{tabular}

Table I(b) shows the axial displacements of the first and second compound gears and of the pinion. Table 1 (c) contains the maximum dynamic transmission errors of the gear pairs. The numbers in these tables are given in dimensionless form. The physical displacements can be recoter ad by multiplying the dimensionless values by the characteristic parameters contained in appendix $B$. As shown in Table I(a), the vibration amplitude of the first compound gear increases as the pinion is placed closer to the output bull gear; this closeness is measured by the angle $\alpha_{p}$ (Fig. 2). Installing the pinion closer to the output' bull gear decreases the vibration amplitudes of the pinion shaft and has almost no effect on the wutput shaft vibrations. The data of Table I(b) shows that bringing the pinion gear closer to the output gear reduces the axial movernent of the compound gears and the pinion shaft. The data of Table I(c) depicts that the dynamic transmission errors of the first compound gear mesh, $\Psi_{p}-\Psi_{1 h}$, and the first output spur mesh, $\Psi_{18}-\Psi_{B}$, decreases with moving the pinion toward the output gear while the dynamic transmission error of the pinion and the second compound gear, $\Psi_{p}-\Psi_{2 h}$ increases.

Tables II(a) to (c) present similar results as those of Tables I(a), to (c), except here, the mesh stiffness phase difference is varied to determine its influence on the response of the system. The data of Table II(a) indicates that as the phase difference between the stiffnesses of the helical pinion and the two compound gears increases, the amplitude of lateral vibration increases for all shafts. However, an increase of the phase difference decreases the axial vibration for the pinion shaft and the two compound gears (Table II(b)). The data of Table II(c) indicates that an increase in the phase difference causes an increase in the dynamic transmission errors of the meshing gear pairs. These results show that the shaft locations and stiffness tuning are significant design parameters that influence the motions of the system. Optimization techaiques should be applied with this analysis to determine the optimum shaft locations and mesh stiffness tuning parameters.

The periodic, time-variable mesh stiffness categorizes the gear train as a parametrically excited dynamic system. The simulated motions of the system shown in Figs. 7 to 16 are consistent with typical responses of a parametrically excited system with high frequency characteristics restrained by a low-frequency envelope. Also, dynamic instabilities similar to those observed in systems expressed by Mathieu's equations are expected under certain operating conditions (Nayfeh, 1979). Unlike externally excited systems in which a small excitation produces large response oaly if the excitation frequency is close to one of the natural frequencies of the system, a small parametric excitation can potentially produce a large response when the excitation frequency is close to one-half of one of the natural frequencies of the system. In such cases, if the system is purely linear, theoretically the response amplitude increases to infinity. However, most physical dynamic systems possess some degree of nonlinearity which influences the system's response as soon as the amplitude of motion grows beyond certain limits. Hence, the linear theory is only useful in determining the initial growth or decay of the system response. The dynamic system studied in this work has been modeled as a linear system with parametric excitations. However, the physical system possesses some inherent nonlinear characteristics such as the gear mesh backlash and hardening bearing stiffnesses which influence the motion of the physical system. These nonlinear effects are not included in the theoretical model presented in this work. The large amplitudes of vibrations for $\Psi_{1 \mathrm{~s}}-\Psi_{B}$ as shown in Table II(c) are thought to be the results of instabilities inherent in parametrically excited linear systems and not representative of the nonlinear physical system.

As mentioned earlier, although the split-torque gear train is geometrically symmetric with respect to the centerline of the bull and pinion gears, the dynamic behavior of the first and second compound gears are not the same; this can be seen by comparing Figs. 7 to 10 , respectively. The difference between the vibrations of the two compound gears has been observed in an experiment conducted by the Sikorsky Helicopter Company as a part of the Advanced Rotorcraft Transmission Project (Kish, 1992). This difference may be the result of unequal static bearing reactions of the two compound gears.

Figures 11 and 12 show the axisl displacements of the two compound gears. The static transmission errors of the two power paths were considered slightly different in the dynamic simulation of the gear train; this is a realistic condition which will arise due to manufacturing limitations of making two exactly matched compound gear assemblies. The difference between the simulated static transmission errors may be the cause for the slight phase difference between the axial motion of the two compound gears, $Z_{1}$ and $Z_{2}$, as depicted in Figs. 11 and 12. The phase shift between the axial motions of the two compound gears indicates that the balance beam has a rocking motion in the simulated dynamic operation of the gear train.

Figures 13 to 16 are the dynamic transmission errors of pairs of the helical and spur gear meshes of the two power paths. respectively. The differences in the responses of the corresponding mesh pairs may be the result of the nonsymmetric bearing reactions of the power paths as well as the small differences in the simulated static transmission errors in each power pach.

The mathematical model presented in this work may be employed in an optimization process to determine the optimum 
values of the geometric and material properties of the subcomponents of the gear train.

\section{SUMMARY OF RESLLTS}

A mathematical model has been developed to analyze the dynamic and vibration characteristics of split-torque transmissions. The model consists of 18 equations of motion. The equations were developed using the Lagrangian method and solved using a fifthorder/sixth-order Runge-Kutta method. The model was demonstrated with a test case. The source of excitation for the model was simulated static transmission errors for each gear pair. Parametric studies were also conducted to examine the effects of two design parameters, shaft location, and mesh stiffness tuning, on the performance of the gear train. The following specific results were obtained:

1. The simulated motions of the sytem are consistent with typical responses of a parametrically excited sytem with highfrequency cheracteristics restrained by a low-frequency envelope.

2. The large amplitudes of vibrations in some of the simulated motions are thought to be the results of instabilities inherent in parametrically excited linear systems and not represenative of the nonlinear physical system.

3. Although the split-torque gear train is geometrically symmetric, the simulated dynamic behavior of the first and second compound gears are not the same.

4. The shaft location and mesh stiffness tuning are significant design parameters that influence the motions of the system

\section{REFERENCES}

August, R., Kasuba, R., Frater, J., and Pintz, A.: Dynamics of Planetary Gear Trains, NASA Contractor Report 3793, Grant NAG3-186, June 1984.

Choy, F.K., Townsend, D.P., and Oswald, F.B.: Experimental and Analytical Evaluation of Dynamic Load and Vibration of a 2240-kW (3000 hp) Rotorcraft Transmission, NASA T.M-88975, presented at the ASME Design Engineering Conference, Chicago, March 2-5, 1987.

Choy, F.K., Townsend, D.P., and Oswald, F.B.: Dynamic Analysis of Multimesh-Gear Helicopter Transmission, NASA TP-2789, February 1988.

Coy, J.J., and Bill, R.C.: Advanced Transmission Studies, NASA TM-100867, A VSCOM TR 88-C-002, presented at 44th Annual Forum of the American Helicopter Society, Washington D.C., June 16-18, 1988.

Fischer G.: Advanced Power Transmission Technology, Proc. of a symposium sponsored by Propulsion Laboratory, AVRADCOM Research and Technology Laboratories and NASA Lewis Research Center, Cleveland, Ohio, June 9-11, 1981.

Hochmann, D., Smith, D., Thomas, J., and Houser, D.R.:

Transmission Error and Load Distribution Analysis of Spur and Double Helical Gear Pair Used in a Split Path Helicopter

Transmission Design, presented at AHS Technical Specialists Meeting, Philadel phia, October 15-16, 1991.

Kish, J: Advanced Rotorcraft Transmission Program Final Report, NASA Contractor Report In Process, 1992.

Nayfeh, Ali H., and Mook, Dean T.: Nonlinear Oscillations, Pure and Applied Mathematics, A Whiley-Interscience Series of Texts, ISBN:0-471-03555-6, 1979.

Singh, R., and Lim, T.C.: Vibration Transmission Through Rolling Element Bearings in Geared Rotor Systems, VASA CR-4334, A VSCOM TR 90-C-019, November 1990.

White G.: New Family of High-Ratio Reduction Gear with Multiple Drive Paths, Proc. Instn. Engrs., Vol. 188, IMech, 1974, pp. 281-288.
White, G.: 3600 hp Split-Torque Helicopter Transmission, NASA Report CR 174932, 1985.

White, G.: Design of A $375 \mathrm{KW}$ Helicopter Transmission with Split-Torque Epicyclic and Bevel Drive Stages, Proc. Instn. Mech. Engrs., Part C, 1983, 197, pp. 213-224.

White, G.: Split-Torque Helicopter Transmission with Widely Separated Engines, Proc. Instn Mech. Engrs., Vol 203, MMech, 1989, pp. 53-65.

White G.: Design Study of Split-Torque Helicopter Transmissions, NASA Technical Report NAS3-22528, 1982.

Zakrajsek, J.: Comparison Study of Gear Dynamics Computer Programs at NASA Lewis Research Center, NASA Technical Paper 2901, March 1989.

\section{APPENDIX A - TYPICAL EQUATION OF MOTION OF THE}

\section{SPLIT-TORQUE TRANSMISSION}

The system nas 18 equations of motion.

The equation of lateral displacement of the first compound gear, $Y_{1}$, is presented below:

$$
\begin{aligned}
& M_{1} \ddot{Y}_{1}+\left\{\operatorname{Cos}^{2}(\beta) K_{1 m h}+\operatorname{Cos}^{2}\left(\alpha_{1}\right) K_{1 m s}\right. \\
& +\left[r_{p} \operatorname{Cos}^{2}(\beta) K_{1 m h}\right]^{2} / r_{p}{ }^{2} \operatorname{Cos}^{2}(\beta)\left(K_{1 m h}-K_{2 m h}\right)+K_{s p i} \\
& \left.+K_{y \mathrm{BB} 1}\right\} Y_{1}-\left\{\operatorname{Sin}\left(\alpha_{1}\right) \operatorname{Cos}\left(\alpha_{1}\right) K_{1 \operatorname{mos}}\right\} X_{1} \\
& -\left\{\left[\left(\mathrm{r}_{\mathrm{p}} \operatorname{Cos}^{2}(\beta) \mathrm{K}_{1 \mathrm{mh}}\right)\left(\mathrm{r}_{\mathrm{p}} \operatorname{Cos}^{2}(\beta) \operatorname{Sin}\left(\alpha_{\mathrm{p}}\right) \mathrm{K}_{2 \mathrm{mbh}}\right] / \mathrm{r}_{\mathrm{p}}{ }^{2} \operatorname{Cos}^{2}(\beta)\left(\mathrm{k}_{1 \mathrm{mh}}\right.\right.\right. \\
& \left.\left.+K_{2 m h}\right)+K_{s p j}\right\} X_{p} \\
& -\left\{\operatorname{Cos}^{2}(\beta) K_{1 m h}\right. \\
& -\left[\left(r_{p} \operatorname{Cos}^{2}(\beta) K_{1 m h}\right)\left(r_{p} \operatorname{Cos}^{2}(\beta)\left(K_{1 m h}-\operatorname{Cos}\left(\alpha_{p}\right) K_{2 m h}\right)\right)\right] / \\
& \left\{r_{p}^{2} \operatorname{Cos}^{2}(\beta)\left(K_{1 m h}+K_{2 m h}\right)+K_{s p j}\right\} Y_{p} \\
& -\left\{\mid\left(r_{p} \operatorname{Cos}^{2}(\beta) K_{1 m h}\right)\left(r_{p} \operatorname{Cos}^{2}(\beta) K_{2 m h} i / r_{p}{ }^{2} \operatorname{Cos}^{2}(\beta)\left(k_{1 m h}+K_{2 m h}\right)\right.\right. \\
& \left.+\mathrm{K}_{\mathrm{sp}}\right\} \mathrm{Y}_{2}-\left\{\operatorname{Cos}\left(\alpha_{1}\right) \mathrm{K}_{1 \mathrm{~ms}}\right\} \mathrm{Y}_{\mathrm{B}} \\
& +\left\{\operatorname{Cos}(\beta) \operatorname{Sin}(\beta) \mathrm{K}_{1 \mathrm{mh}}+\mid\left(\mathrm{r}_{\mathrm{p}} \operatorname{Cos}^{2}(\beta) \mathrm{K}_{1 \mathrm{mh}}\right)\left(\mathrm{r}_{\mathrm{p}} \operatorname{Cos}(\beta) \operatorname{Sin}(\beta) \mathrm{K}_{1 \mathrm{mhh}}\right) j\right. \\
& \left.\left[\mathbf{r}_{\mathrm{p}}^{2} \operatorname{Cos}^{2}(\beta)\left(k_{1 \mathrm{mh}}+K_{2 \mathrm{mh}}\right)+K_{\mathrm{sp}}\right]\right\} \mathrm{Z}_{1} \\
& -\left\{\left(\left(r_{p} \operatorname{Cos}(\beta) \operatorname{Sin}(\beta) K_{2 m h}\right)\left(r_{p} \operatorname{Cos}^{2}(\beta) K_{2 m h}\right] / / r_{p}{ }^{2} \operatorname{Cos}^{2}(\beta)\left(K_{1 m h}\right.\right.\right. \\
& \left.\left.+\mathrm{K}_{2 \mathrm{mh}}\right)+\mathrm{K}_{\mathrm{sp}}\right\} \mathrm{Z}_{2}-\left\{\operatorname{Cos}(\beta) \operatorname{Sin}(\beta) \mathrm{K}_{1 \mathrm{mh}}\right. \\
& +\left[( \mathbf { r } _ { \mathrm { p } } \operatorname { C o s } ^ { 2 } ( \beta ) \mathrm { K } _ { 1 \mathrm { mh } } ) \left(\mathbf{r}_{\mathrm{p}} \operatorname{Cos}(\beta) \operatorname{Sin}(\beta)\left(\mathrm{K}_{1 \mathrm{mh}}+\mathrm{K}_{2 \mathrm{mh}}\right) \mathrm{j} /\right.\right. \\
& {\left[\mathrm{r}_{\mathrm{p}}^{2} \operatorname{Cos}^{2}(\beta)\left(\mathrm{K}_{1 \mathrm{mh}}+K_{2 \mathrm{mh}}\right)+K_{\mathrm{ap}}\right] \mathrm{Z}_{\mathrm{p}}} \\
& -\left\{\left(\left(K_{\mathrm{sp}}\right) \mathrm{r}_{\mathrm{p}} \operatorname{Cos}^{2}(\beta) \mathrm{K}_{2 \mathrm{mh}}\right] /\left[\mathrm{s}_{\mathrm{p}} 2 \operatorname{Cos}^{2}(\beta)\left(\mathrm{k}_{1 \mathrm{mh}}+\mathrm{K}_{2 \mathrm{mhh}}\right)+\mathrm{K}_{\mathrm{sp}}\right\} \Psi_{\mathrm{i}}\right. \\
& +\left\{r_{1 h} \operatorname{Cos}^{2}(\beta) K_{1 m h}+\left\{\left(r_{p} \operatorname{Cos}^{2}(\beta) K_{1 m h}\right)\left(r_{p} r_{1 h} \operatorname{Cos}^{2}(\beta) K_{1 m h}\right)\right\} /\right. \\
& \left\{\mathrm{r}_{\mathrm{p}}{ }^{2} \operatorname{Cos}^{2}(\beta)\left(\mathrm{k}_{1 \mathrm{mh}}-\mathrm{K}_{2 \mathrm{mh}}\right)+\mathrm{K}_{\mathrm{sp}} \mathrm{j}\right\} \Psi_{1 \mathrm{~h}} \\
& \text { - }\left\{\left(\left(r_{\mathrm{p}} \operatorname{Cos}^{2}(\beta) K_{1 \mathrm{mh}}\right)\left(r_{\mathrm{p}} \mathrm{r}_{2 \mathrm{~h}} \operatorname{Cos}^{2}(\beta) \mathrm{K}_{2 \mathrm{mh}}\right)\right] / / \mathrm{r}_{\mathrm{p}}{ }^{2} \operatorname{Cos}^{2}(\beta)\left(K_{1 \mathrm{mh}}\right.\right. \\
& \left.\left.-K_{2 m h}\right)+K_{s p l}\right\} \Psi_{2 h}+\left\{r_{1 s} \operatorname{Cos}\left(\alpha_{1}\right) K_{1 m s}\right\} \Psi_{1 s} \\
& -\left\{r_{B} \operatorname{Cos}\left(\alpha_{1}\right) K_{1 m s}\right\} \Psi_{1 B}+C_{2,2} \dot{Y}_{1}+C_{2,1} \dot{X}_{1}
\end{aligned}
$$


$+\mathrm{C}_{2,3} \dot{\mathrm{X}}_{\mathrm{p}}+\mathrm{C}_{2,4} \dot{\mathrm{Y}}_{\mathrm{p}}+\mathrm{C}_{2,6} \dot{\mathrm{Y}}_{2}+\mathrm{C}_{2,8} \dot{\mathrm{Y}}_{\mathrm{B}}$

$+\mathrm{C}_{2,9} \dot{\mathrm{z}}_{1}+\mathrm{C}_{2,10} \dot{\mathrm{z}}_{2}+\mathrm{C}_{2,11} \dot{\mathrm{z}}_{\mathrm{p}}$

$+C_{2,12} \dot{\Psi}_{i}+C_{2,13} \dot{\Psi}_{1 h}+C_{2,14} \dot{\Psi}_{2 h}+C_{2,15} \dot{\Psi}_{1 \mathrm{~s}}+C_{2,17} \dot{\Psi}_{\mathrm{B}}$

$=-\left\{\left[-K_{1 m h} \operatorname{Cos}(\beta)+\left(r_{p}{ }^{2} \operatorname{Cos}^{2}(\beta) K_{1 m h}{ }^{2}\right) /\left(r_{p}{ }^{2} \operatorname{Cos}^{2}(\beta)\left(K_{1 m h}\right.\right.\right.\right.$

$\left.\left.\left.+K_{2 \mathrm{mh}}\right)+K_{\mathrm{sp}}\right)\right] e_{1 h}(t)$

$+\left[\left(r_{p} \operatorname{Cos}^{2}(\beta) K_{1 m h} K_{2 m h}\right) /\left(r_{p}{ }^{2} \operatorname{Cos}^{2}(\beta)\left(K_{1 m h}+K_{2 m h}\right)+K_{s p}\right)\right]$

$\left.x e_{2 h}(t)-\left[K_{1 m s} \operatorname{Cos}\left(\alpha_{1}\right)\right] e_{1 s}(t)\right\}$

\section{APPENDIX B - DIMENSIONLESS ANALYSLS}

The equations of motion are expressed in dimensionless forms, using certain characteristic parameters inherent in the gear train system. The characteristic parameters are:

Length $=\bar{E}_{p}$, where $\bar{E}_{p}$ is the mean value of the displacement element function of the pinion and helical compound gear

Time $=1 / \omega_{p}$, where $\omega_{p}$ is the pinion speed, $\mathrm{rad} / \mathrm{sec}$

Force $=\overline{\mathrm{E}}_{\mathrm{p}} \overline{\mathrm{K}}_{1 \mathrm{mh}}$, where $\overline{\mathrm{K}}_{1 \mathrm{mh}}$ is the mean value of the time varying mesh characteristic stiffness of the pinion-compound mesh

Torque $=\left(\bar{E}_{p} \bar{K}_{1 m h}\right) r_{p}$, where $r_{p}$ is the pinion's base circle radius

$$
\text { Angle }=\overline{\mathrm{E}}_{\mathrm{p}} / \mathrm{r}_{\mathrm{p}}
$$

Using the above characteristic parameters, the following dimensionless parameters may be defined:

Time $=\omega t$

Linear displacement $=$ displacement $/ \bar{E}_{p}$

Angular displacement $=\left(r_{p} / \bar{E}_{p}\right)$ angular displacement Inertia in linear displacement equation $=\mathrm{M} \omega_{\mathrm{p}}^{2} / \overline{\mathrm{K}}_{1 \mathrm{mh}}$ Inertia in angular displacement equation $=I \omega_{p}^{2} / r_{p}^{2} \bar{K}_{1 m h}$

Damping of linear displacement in linear equation of motion $=\omega_{\mathrm{p}} \mathrm{C} / \overline{\mathrm{K}}_{1 \mathrm{mh}}$

Damping of linear disriacement in angular equation of motion $=\omega_{p} C / r_{p} \bar{K}_{1 m h}$

Damping of angu'ar displacement in linear equation of motion $=\omega_{p} C / r_{p} \bar{K}_{1 m h}$

Damping of angular displacement in angular equation of motion $=\omega_{p} \mathrm{C} / \mathbf{r}_{\mathrm{p}}^{2} \overline{\mathrm{K}}_{1 \mathbf{m h}}$
Stiffness of linear displacement in linear equation of motion $=\mathrm{K}(\mathrm{t}) / \mathrm{K}_{1 \mathrm{mh}}$

Stiffness of linear displacement in angular equation of motion $=K(t) / r_{p} \bar{K}_{1 m h}$

Stiffness of angular displacement in linear equation of motion $=K(t) / r_{p} \bar{K}_{1 m h}$

Stiffness of angular displacement in angular equation of motion $=K(t) / r_{p}^{2} \bar{K}_{1 m h}$

Force $=$ force $/\left(\overline{\mathrm{E}}_{\mathrm{p}} \mathrm{R}_{1 \mathrm{mh}}\right)$

Torque $=$ torque $/\left(r_{p} \bar{E}_{p} \bar{K}_{1 m h}\right)$

The above dimensionless parameters were employed to carry out a computer simulation of the dynamics of this gear train.

APPENDIX C - DIMENSIONS AND PROPERTIES OF SPLIT

\section{TORQUE TRANSMISSION}

DIMENSIONS AND PROPERTIES OF SALT TORQUE TRANSMISSION

\begin{tabular}{|c|c|c|c|c|}
\hline Gear desicn & $\begin{array}{l}\text { Helical } \\
\text { pinion }\end{array}$ & $\begin{array}{l}\text { Helical rear } \\
\text { of compound } \\
\text { gear }\end{array}$ & $\begin{array}{l}\text { Spur pinion } \\
\text { of compouod } \\
\text { gear }\end{array}$ & $\begin{array}{l}\text { Buill } \\
\text { gear }\end{array}$ \\
\hline $\begin{array}{l}\text { Number of teeth } \\
\text { Ptteh diameter (mm) } \\
\text { Face width (mm) } \\
\text { Normal precoure } \\
\text { angle (des) } \\
\text { Helix angle (deg) }\end{array}$ & \begin{tabular}{c|}
32 \\
51.1 \\
44.5 \\
20.0 \\
6.0
\end{tabular} & $\begin{array}{c}124 \\
197.9 \\
38.1 \\
20.0 \\
6.0\end{array}$ & $\begin{array}{c}27 \\
68.6 \\
66.0 \\
25.0 \\
-\ldots\end{array}$ & $\begin{array}{c}176 \\
447.0 \\
59.9 \\
25.0 \\
\ldots \ldots\end{array}$ \\
\hline
\end{tabular}

\begin{tabular}{|c|c|c|c|c|c|}
\hline Bearing deaigh & $\begin{array}{l}\text { Input } \\
\text { pinion } \\
\text { roller } \\
\text { bearins }\end{array}$ & $\begin{array}{c}\text { Ioput } \\
\text { pinios } \\
\text { ball } \\
\text { bearing } \\
\text { (Duplex) }\end{array}$ & $\begin{array}{l}\text { Compound } \\
\text { sear rolles } \\
\text { bearing }\end{array}$ & $\begin{array}{c}\text { Bull } \\
\text { gear ball } \\
\text { bearing }\end{array}$ & $\begin{array}{l}\text { Bull gear } \\
\text { rollet } \\
\text { bearleg }\end{array}$ \\
\hline $\begin{array}{l}\text { Inser race } \\
\text { diameter (mm) }\end{array}$ & 50.0 & 48.9 & 87.4 & 109.1 & 113.0 \\
\hline $\begin{array}{l}\text { Outer race } \\
\text { diemeter (mm) }\end{array}$ & 69.1 & 71.3 & 66.5 & 140.9 & 133.9 \\
\hline $\begin{array}{l}\text { Number rolling } \\
\text { elemeats }\end{array}$ & 13 & 14 & 15 & 14 & 23 \\
\hline $\begin{array}{l}\text { Rolling element } \\
\text { diameter (mm) }\end{array}$ & 9.53 & 11.13 & 10.67 & 15.88 & 10.46 \\
\hline $\begin{array}{l}\text { Roller length } \\
\text { (mm) }\end{array}$ & 13.20 & $\ldots$ & 10.67 & -.... & 10.41 \\
\hline $\begin{array}{l}\text { Contect angle } \\
\text { (deg) }\end{array}$ & -... & 29 & $\cdots$ & 0 & $\cdots$ \\
\hline
\end{tabular}

\begin{tabular}{|c|c|c|c|}
\hline & $\underset{k g}{\text { Man. }}$ & & $\begin{array}{c}\text { Moment of } \\
\text { inertich } \\
\mathrm{kg}-\mathrm{m}^{2}\end{array}$ \\
\hline $\begin{array}{l}\text { Hellical pinion } \\
\text { Compound gear } \\
\text { Bull coer }\end{array}$ & $\begin{array}{r}2.0 \\
1.6 \\
20.5\end{array}$ & $\begin{array}{l}\text { Input } \\
\text { Helieal goar } \\
\text { Spur pinios } \\
\text { Bull gane } \\
\text { Output }\end{array}$ & $\begin{array}{r}0.003 \\
.010 \\
.003 \\
.028 \\
.880\end{array}$ \\
\hline
\end{tabular}


Public reporting burden for this collection of information is estimated to average 1 hour per response, including the time lor reviewing instructions, searching existing data sources. gathering and maintaining the data needed, and completing and reviowing the collection of intormation. Send comments regarding this burden estimate or any other aspect of this collection of intormation including suggestuons for reducing this burden, to Washington Headquarters Services, Directorate for intormation Operations and Davis Highway, Sute 1204. Arlington, VA 22202-4302, and to the Otfice of Management and Budget, Paperwork Reduction Project (0704-0188). Washington, DC 20503.

\begin{tabular}{|l|c|c|}
\hline 1. AGENCY USE ONLY (Leave blank) & $\begin{array}{c}\text { 2 REPOAT DATE } \\
1992\end{array}$ & $\begin{array}{r}\text { 3. REPOAT TYPE AND DATES COVEAED } \\
\text { Technical Memorandum }\end{array}$ \\
\hline
\end{tabular}

4. TITLE AND SUBTITLE

Dynamics of a Split Torque Helicopter Transmission

Majid Rashidi and Timothy Krantz

\section{FUNDING NUMBERS}

WU-505-63-36

1L162211A47A

\begin{tabular}{l} 
6. AUTHOR(S) \\
Majid Rashidi and Timothy Krantz \\
\hline 7. PERFORIMNG ORGANIZATTON NAME(S) AND ADDRESS(ES) \\
NASA Lewis Rescarch Center \\
Cleveland, Ohio $44135-3191$ \\
and \\
Propulsion Directorate \\
U.S. Army Aviation Systems Command \\
Cleveland. Ohio $44135-3191$
\end{tabular}

9. SPONSORING/MONTORING AGENCY MAMES(S) AND ADDRESS(ES)

National Aeronautics and Space Administration

Washington, D.C. 20546-0001

and

U.S. Army Aviation Systems Command

St. Louis, Mo. 63120-1798
8. PERForimag oRcanization REPOAT NUMBER

E-7060

\section{SUPPLEMENTARY NOTES}

Prepared for the Sixth International Power Transmission and Gearing Conference sponsored by the American Society of Mechanical Engincers,

Scottsdale. Arizona, September 13-16, 1992. Majid Rashidi, Cleveland State University, Mechanical Engincering Department, Cleveland, Ohio 44I15.

Timothy Krantz. Propulsion Directorate, U.S. Army Aviation Systems Command. Responsible person, Timothy Krantz, (216) 433-3580.

12. DISTAIBUTION/AVALABILITY STATEMENT

Unclassified - Unlimited

Subject Category 37 12b. DISTRIBUTHON CODE

\section{ABSTRACT (Miaximum 200 mords)}

A high reduction ratio split torque gear train has been proposed as an alternative to a planetary configuration for the final stage of a helicopter transmission. A split torque design allows a high ratio of power-to-weight for the transmission. The design studied in this work includes a pivoting beam that acts to balance thrust loads produced by the helical gear meshes in each of two parallel power paths. When the thrust loads are balanced, the torque is split evenly. A mathematical model was developed to study the dynamics of the system. The effects of time varying gear mesh stiffness, static transmission errors, and flexible bearing suppons are included in the model. The model was demonstrated with a test case. Results show that although the gearbox has a symmetric configuration, the simulated dynamic behavior of the first and second compound gears are not the same. Also, results show that shaft location and mesh stiffness tuning are significant design parameters that influence the motions of the system.

\begin{tabular}{|c|c|c|c|}
\hline \multirow{2}{*}{\multicolumn{3}{|c|}{$\begin{array}{l}\text { 14. SUBNECT TERMS } \\
\text { Split torque gearbox; Gear dynamics; Load sharing; Transmission error }\end{array}$}} & \multirow{3}{*}{$\begin{array}{c}\text { 15. MUMBER OF PAOES } \\
14 \\
\text { 16. PAICE COOE } \\
\text { A03 }\end{array}$} \\
\hline & & & \\
\hline & & & \\
\hline $\begin{array}{l}\text { 17. SECUATY CLABSHFICATION } \\
\text { OF AEPOAT }\end{array}$ & $\begin{array}{l}\text { 18. SECUATY CLASSEFICATION } \\
\text { OF THS PACE }\end{array}$ & $\begin{array}{l}\text { 19. SeCUamY CLASGAFATION } \\
\text { OF ABSTRACT }\end{array}$ & 20. URITATION OF ABSTAACT \\
\hline Unclassified & Unclassified & Unclassified & \\
\hline
\end{tabular}

